Received: 08/06/2018

Revision: 05/09/2018

Accepted: 09/09/2018

OnlineFirst: 04/10/2018

\title{
Investigating the Effect of Noticing on EFL Students' Speaking Accuracy
}

\section{Hossein Navidinia}

Asst. Prof., corresponding author: Department of English Language, University of Birjand, Birjand, Iran, navidinia@birjand.ac.ir

\section{Mohsen Mobaraki}

Assoc. Prof., Department of English Language. University of Birjand, Birjand, Iran, mmobaraki@birjand.ac.ir

\section{Farzaneh Malekzadeh}

MA student of General Linguistics, Department of English Language, University of Birjand, Birjand, Iran, malekzade.farzane@yahoo.com

The present study aims at investigating the effect of noticing on English as a Foreign Language (EFL) students' speaking accuracy. For so doing, 32 Iranian EFL students were selected and randomly assigned to two conversation classes namely, control and experimental groups. Before the treatment both groups had a speaking pre-test. During 32 sessions of instruction, both classes were taught EFL conversation based on Communicative Language Teaching (CLT) approach. However, in the experimental group, in order to help learners notice the input more, the students were asked to record their authentic conversations, presentations, and dialogues in the class. Then, they were asked to transcribe their voices and identify their grammatical, phonological and lexico-semantic errors based on Keshavarz's (1999) Model of Error Analysis. Their teacher also checked their voice files and transcriptions in order to help them identify their errors. After the treatment both groups had a speaking post-test. Then, the number of speaking errors the two groups had in the pre-test and post-test were compared using ANCOVA. The results indicated that the EFL learners in the experimental group had a significantly lower number of speaking errors in the post-test compared with that of the control group which confirmed the positive effect of noticing on EFL students' speaking accuracy.

Keywords: speaking, accuracy, EFL learners, noticing, errors

\section{INTRODUCTION}

With the unprecedented spread of English language as the 'lingua franca' of the global village, more and more individuals need to learn this language in order to satisfy their communicative needs. According to Richards (2008) "the mastery of speaking skills in

Citation: Navidinia, H., Mobaraki, M., \& Malekzadeh, F. (2019). Investigating the Effect of Noticing on EFL Students' Speaking Accuracy. International Journal of Instruction, 12(1), 83-98. https://doi.org/10.29333/iji.2019.1216a 
English is a priority for many second-language or foreign language learners" (p. 19). Accordingly, English Language Teaching (ELT) methods have tried to help learners develop their 'communicative competence'.

However, learning speaking is not an easy task for many language learners especially in EFL contexts where they have meagre exposure to the authentic language outside the class. Previous studies have indicated that because of many factors such as the paucity of input, interference of mother language, and the like, EFL learners may have different types of errors while speaking (Gan, 2012; Lee, 2009; Morita, 2000; Muhamad, et al., 2013; Nazarloo \& Navidinia, 2016). Although it is generally accepted by almost all scholars in the field that errors are an integral part of language learning process and students should be helped to correct their errors, the same consensus have not been shared about how to treat students' errors.

One of the controversial issues in language teaching has been the level of "conscious or unconscious attention" which is needed in the process of second/foreign language learning (Schmidt, 1990, p. 129). Some scholars such as Krashen (1981, 1982, 1985) maintained that second language development is similar to first language acquisition and no explicit instruction or conscious attention are needed for language learning. According to his 'Natural Approach', 'comprehensible input', which is the basis of 'input hypothesis', is needed for second language learning. However, the findings of some naturalistic and immersion programs indicated that if the sole focus of instruction is on meaning, students cannot accurately learn some linguistic features (Williams, 1999).

Therefore, to compensate for the shortcomings of naturalistic approach to language learning, Schmidt (1990) proposed the Noticing Hypothesis claiming that noticing or the conscious attention "is the necessary and sufficient condition for converting input to intake" (p. 129). He argued that similar to "behaviorists who assumed that their subjects left their mental faculties outside the laboratory door, we have assumed learner ignorance was more often than we have attempted to investigate learner awareness" ( $p$. 150 ), and called for "much more research into what learners are conscious of as they learn second languages" (p. 149).

The core of the Noticing Hypothesis in simple term is that "people learn about the things that they pay attention to and do not learn much about the things they do not attend to" (Schmidt, 2010, p. 722). Schmidt (1990) further maintained that the role of conscious attention has been underestimated while it is "useful because it ties together such related concepts as attention, short term memory, control vs. automatic processing, and serial vs. parallel processing" (p. 131).

Previous studies have shown a general positive effect of noticing on language learning (Abdalla, 2014; Baleghizadeh \& Derakhshesh, 2012; Bergsleithner, 2007; Jafarpour Mamaghani \& Birjandi, 2017; Khatib \& Alizadeh, 2012; Izumi, 2013; Mackey, 2006; Mennim, 2007; Mirzaei, Abdollahian, \& Ranjbar, 2012; Schmidt \& Frota, 1986). In a relatively recent study, Ögeyik (2017) reviewed and compared 41 published studies on the effectiveness of noticing in language learning which were conducted in different 
countries from 2008 to 2016. The researcher used 'narrative meta-analysis' to review the studies. Having reviewed the studies, the researcher found compelling evidence supporting the positive effect of noticing on learning different language skills. Therefore, the findings of this study provided a global support for the 'Noticing Hypothesis'.

In another study, Baleghizadeh and Derakhshesh (2012) tried to examine the effect of task repetition and reactive focus on form on the oral output of four intermediate Iranian EFL students. The participants voluntarily presented lectures and their voices were recorded. Then, the learners were asked to transcribe their speech and correct their mistakes. The teacher also helped them with their correction and asked them to prepare themselves for the second lecture. The comparison between the number of errors made by the students in the first and second lectures indicated that task repetition had a positive effect on the accuracy of students' oral performance. However, the extent to which the improvement in the students' second performance was due to noticing or other factors such as memorization or the fact that they knew more about the topic of presentations was not clear. Besides, the participants were just 4 students who presented 2 times can limit the generalizability of the findings. Moreover, no feedback on the students' phonological and semantic errors was given in this study.

Similarly, Mennim (2007) examined the long-term effects of noticing on oral output of Japanese English language learners by giving them classroom activities which could promote their noticing and conscious attention to form. During one academic year, the students were given some tasks that help them notice L2 forms. The students' oral output was recorded and analyzed to check for potential improvements in the use of the forms they had noticed. After the treatment, the author concluded that noticing had positive effects on students' language accuracy and help them correct their errors. Although the number of participants was only 17, the fact that the study was conducted during nine month could contribute to the reliability of the findings.

Furthermore, Jafarpour Mamaghani and Birjandi's (2017) study investigated the effect of oral pushed output on the learning and retention of English perfect tenses. Their participants were 22 students majoring in English translation who were randomly assigned to two groups (control and experimental). For six sessions, both groups were taught English perfect tenses explicitly. However, every session, the learners in the experimental group were asked to record their oral performances on some picture description and translation tasks whose completion entailed the use of the instructed language form, while the control group answered some multiple choice questions. The findings of this study supported the facilitative effects of oral pushed output (although it was not interactive) on the learning and retention of English perfect tenses.

In addition, Mirzaei, Abdollahian, and Ranjbar (2012) investigated the effect of noticing on 80 low-intermediate and upper-intermediate EFL students' use of correct English intonation patterns. Students in both levels were divided into experimental and control groups. While listening to native speakers' English audio-recorded on a CD, the experimental groups received noticing-enhancing instruction, repeated activation of intonation patterns, metalinguistic explanations, picture descriptions, and interactive 
role-playings. At the end of the experiment, the author hired a native speaker to rate the students' recorded voices at both pretest and posttest. The results indicated that the experimental groups achieved a noticeable improvement in their posttest compared with their pretest. However, although the findings emphasized the facilitative effect on noticing on EFL students' intonation patterns, the long-term effect of noticing on students' performance, and the potential influence of students' individual characteristics were not investigated in this study.

However, most of the previous studies have examined the effect of noticing on learning some grammatical or linguistic features, but comprehensive studies investigating the effect of noticing on EFL students' speaking accuracy are lacking. To the best the authors' knowledge, no previous studies have comprehensively addressed the impact of noticing on EFL students' speaking accuracy. Therefore, the present study aims to examine the effect of students' noticing on their grammatical, phonological, and lexicosematic accuracy while speaking by asking them to transcribe their voices and find the errors based on Keshavarz' (1999) Framework of Errors Analysis. In other words, given the difficulties that EFL students have while learning EFL speaking skill, this study tries to investigate if noticing can significantly decrease the number of their speaking errors.

\section{METHOD}

\section{Participants}

The participants of this study were two intact groups including 32 upper-intermediate university students. They were admitted as freshman students in the field of English Language and Literature at the University of Birjand in Iran in the Fall Semester of 2017. Twelve of them were male and 20 were female. Their age mean was 18 years.

\section{Procedure}

The students were divided into two groups namely, experimental and control. Then, during the term, the participants in the experimental group were asked to present lectures, participate in the classroom dialogues and discussions, and answer to some oral questions in the class, and their voices were recorded. Then, they were asked to transcribe their voices at home and find the speaking errors that they had based on Keshavarz's (1999) Model of Errors Analysis, and write the correct form of the errors they had. Briefly speaking, Keshavarz's (1999) Model of Errors Analysis classifies errors into three major categories as follow:

1. Morpho-syntactic errors: which refer to grammatical errors including wrong use of plural morpheme, wrong use of parts of speech, wrong use of tenses, wrong sequence of tenses, wrong use of active and passive voice, wrong word order, using 'it is' instead of 'there is', misplacement of adverbs, errors in the use of prepositions, wrong use of prepositions, errors in the use of articles, wrong use of conditional sentences, double negation, wrong use of negative imperative, errors in the use of relative clauses and relative pronouns, subject-verb inversion in WH-questions, wrong use of verb groups, errors due to lack of concord or agreement, and typical Persian construction. 
2. Phonological errors: which are errors due to lack of certain Target Language phonemes in the learner's Native Language, differences in syllable structures of L1 and L2, spelling pronunciation of words, and the problems with silent letters.

3. Lexico-semantic errors: which are related to the semantic properties of lexical items.

Two modifications were applied to this framework based on errors that the participants had in their pre-test. Firstly, two tenses were added to the category of Wrong Use of Tenses based on the error noticed in the students' speaking in the pre-test which were using Past Continuous instead of Simple Past and Simple Present instead of Simple Past. Secondly, in the Phonological section, we added Word Stress since it has a great significance on speaking accuracy.

At the first session of the class, the researchers explained different types of errors based on Keshavarz's Model of Errors Analysis, and gave the students a table based on this model so they could classify and put their errors in right columns. During the term, the teacher listened to the students' voices and checked the 'error tables' that they brought to the class as their assignment to check if they could identify all errors and categorized them correctly based on the Keshavarz's Model. If not, the teacher identified the errors and explained the correct forms for them. Therefore, voice recording, transcribing, and finding and classifying the errors, and explaining the correct forms by the teacher were the steps that were undertaken to help the learners in the Experimental Group to notice the input more for 32 sessions. The students in the Control Group had the same teacher and classroom activates, however, they were not asked to record and transcribe their voices.

\section{Instrumentation and Data Analysis}

Before the start of the experiment, a speaking pretest was taken from the students. Each student was asked a set of general questions. They were asked to give long answers to the questions. The oral test was lasted for around 7 minutes for each participant. After 32 sessions of instruction (each lasted for one hour and a half), a speaking posttest was taken from the students. The students' voices in both pretest and posttest were recorded and transcribed, and the grammatical, phonological and lexico-semantic errors made by them while speaking were calculated. Then, the data were analyzed through One-way ANCOVA using SPSS software.

As the number of the words students said and also the length of their oral test were not precisely the same, and in order to have a more precise calculation and comparison of students' errors, the total number of the words the students said, and also the number of errors they had in their speaking in the pretest and posttest were calculated. Then, the number of errors was divided by the number of words they said to have a more reliable measure for comparison.

\section{FINDINGS}

As we had 4 set of scores (for the experimental and control groups' pretest and posttest), ANCOVA is the best statistical test as it can take into account the pretests scores too. We analyzed the students' errors based on Keshavarz's (1999) Framework for Error 
Analysis which includes grammatical, phonological and lexico-semantic errors. In this section we first examined the effect of Noticing on total speaking errors and then on each of the three components.

\section{Descriptive Statistics}

Table 1 shows the total number of the words the students produced and also the number of errors they had in their speaking in the pretest and posttest. It also includes the descriptive statistics related to the number of errors divided by the number of words said in the pretest and posttest by the learners.

As indicated in the Table, students produced 12873 words in the pretest and 14962 words in the posttest. In general, the students had 1450 and 1018 errors in their pretest and posttest respectively. However, as we wanted to compare the number of errors made by the experimental and control groups in the pretest and posttest with regards to the number of the words that they produced, we divided the total number of errors students made to the total number of the words they produced to have a more exact calculation. As indicated in Table 1, after the calculation, the sum of the posttest was 2.48 and that of the pretest was 4.30 .

Table 1

Descriptive statistics of students' words, and errors in the pretest and posttest

\begin{tabular}{lllllll}
\hline & $\begin{array}{l}\text { Words } \\
\text { Pretest }\end{array}$ & $\begin{array}{l}\text { Words } \\
\text { Posttest }\end{array}$ & $\begin{array}{l}\text { Errors } \\
\text { Pretest }\end{array}$ & $\begin{array}{l}\text { Errors } \\
\text { Posttest }\end{array}$ & $\begin{array}{l}\text { Total Errors in } \\
\text { Pretest Divided by } \\
\text { Words }\end{array}$ & $\begin{array}{l}\text { Total Errors in } \\
\text { Posttest Divided by } \\
\text { Words }\end{array}$ \\
\hline $\mathrm{N}$ & 32 & 32 & 32 & 32 & 32 & 32 \\
Mean & 402.2812 & 467.5625 & 45.3125 & 31.8125 & .1344 & .0776 \\
Std. & $1.14272 \mathrm{E}$ & 154.4102 & 7.14115 & 10.79258 & .05183 & .03798 \\
Deviation & 2 & 1 & & & & .03 \\
Minimum & 159.00 & 176.00 & 27.00 & 13.00 & .07 & .17 \\
Maximum & 636.00 & 784.00 & 66.00 & 62.00 & .28 & 2.48 \\
Sum & 12873.00 & 14962.00 & 1450.00 & 1018.00 & 4.30 & \\
\hline
\end{tabular}

\section{The Influence of Noticing on the Students' Speaking Errors}

In order to examine the effect of Noticing on the students' speaking accuracy, ANCOVA was used. This statistical test has 4 assumptions. Before running this test, these assumptions should be met. The first one is the equality of variances of errors. As indicated in Table 2, Levene's test of Equality of Variances shows that the variances of errors are equal since the Sig. is more than .05. The second assumption of ANCOVA is the normality of residual of the model. As shown in Table 2, Kolmogorov-Smirnov's test shows that the residual of model is normal as the Sig. is more than .05.

The third assumption of ANCOVA is the homogeneity of the regression slope. This assumption is met when the interaction of Group * Total Pretest is not significant (sig. > 
$.05)$. As indicated in Table 2, this assumption was met as the sig. is .304. The fourth assumption of ANCOVA is the linearity of regression line. This assumption is met when the interaction of Total Pretest is significant (Sig. $<.05)$. Therefore, the last assumption was also met as the sig is .000 as indicated in Table 2.

Table 2

Assumptions of ANCOVA

\begin{tabular}{ll}
\hline Assumptions & Sig. \\
\hline Levene's Test of Equality of Error Variances & .555 \\
Kolmogorov-Smirnov's Test of Normality & .056 \\
Tests of Between-Subjects Effects (Homogeneity of the regression slope) & .304 \\
Tests of Between-Subjects Effects (Homogeneity of the regression slope) & .000 \\
\hline
\end{tabular}

As the assumptions of ANCOVA were met, this test was run. As shown in Table 3, the results of ANCOVA indicated a significant difference between the performance of the experimental group in the posttest $(\mathrm{F}=17.105$, sig. $=0.000)$. Therefore, it can be concluded that students in the experimental group had less speaking errors in the posttest which confirms the positive influence of Noticing on reducing students' errors.

Table 3

Tests of Between-Subjects Effects

\begin{tabular}{lllllll}
\hline \multicolumn{7}{c}{ Dependent Variable: Total Posttest } \\
\hline Source & $\begin{array}{l}\text { Type III Sum } \\
\text { of Squares }\end{array}$ & $\mathrm{df}$ & Mean Square & $\mathrm{F}$ & Sig. & Squared \\
Corrected Model & $.031^{\mathrm{a}}$ & 2 & .015 & 31.227 & .000 & .683 \\
Intercept & $7.661 \mathrm{E}-6$ & 1 & $7.661 \mathrm{E}-6$ & .016 & .901 & .001 \\
Total Pretest & .027 & 1 & .027 & 55.968 & .000 & .659 \\
Group & .008 & 1 & .008 & 17.105 & .000 & .371 \\
Error & .014 & 29 & .000 & & & \\
Total & .237 & 32 & & & & \\
Corrected Total & .045 & 31 & & & & \\
\hline
\end{tabular}

Now that the total students' errors based on Keshavarz's (1999) Model of Error Analysis were calculated and compared, we run three other ANCOVA tests separately to examine the effect of Noticing on the three main components of this model which were grammatical, phonological and lexico-semantic errors.

\section{Grammatical Errors}

\section{Descriptive Statistics of Grammatical Errors}

Table 4 indicates the number of grammatical errors that the students had in their pretest and posttest. It shows that the students had less grammatical errors $(\mathrm{Sum}=660)$ in their posttest compared with the number of errors that they had in their pretest $(\mathrm{Sum}=911)$. Moreover, Table 4 shows the number of grammatical errors divided by words in pretest and posttest which are 2.50 and 1.57 respectively. 
Table 4

Descriptive statistics of students' grammatical errors in the pretest and posttest

\begin{tabular}{|c|c|c|c|c|c|c|}
\hline & $\mathrm{N}$ & Minimum & Maximum & Sum & Mean & Std. Deviation \\
\hline $\begin{array}{l}\text { Grammatical Errors in } \\
\text { Pretest }\end{array}$ & 32 & 23.00 & 33.00 & 911.00 & 28.4688 & 2.73548 \\
\hline $\begin{array}{l}\text { Grammatical Errors in } \\
\text { Posttest }\end{array}$ & 32 & 10.00 & 28.00 & 660.00 & 20.6250 & 4.33850 \\
\hline $\begin{array}{l}\text { Grammatical Errors in } \\
\text { Pretest Divided by Words }\end{array}$ & 32 & .04 & .19 & 2.50 & .0782 & .03067 \\
\hline $\begin{array}{l}\text { Grammatical Errors in } \\
\text { Posttest Divided by } \\
\text { Words }\end{array}$ & 32 & .02 & .10 & 1.57 & .0492 & 01973 \\
\hline
\end{tabular}

\section{The Influence of Noticing on Students' Grammatical Accuracy}

As shown in Table 5, Levene's test of Equality of Variances indicates that the variances of errors are equal since the Sig. is more than .05. Thus, this assumption is met for the grammatical accuracy of the learners. Furthermore, as shown in Table 5, KolmogorovSmirnov's test indicates that the residual of the model is normal as the Sig. is more than .05. Therefore, the second assumption of ANCOVA was met.

The third assumption of ANCOVA is the homogeneity of the regression slope. As indicated in Table 5, it was met for the grammatical accuracy of the learners as the sig. is .268. This assumption is met because the interaction of Group * Grammar Pretest is not significant (Sig. > .05). Similarly, the fourth assumption of regression (the linearity of regression line) was also met as the sig. is .000. This assumption is met as the interaction of Grammar Pretest is significant (Sig. < .05).

Table 5

Assumptions of ANCOVA for Students' Grammatical Accuracy

\begin{tabular}{ll}
\hline Assumptions & Sig. \\
\hline Levene's Test of Equality of Error Variances & .386 \\
Kolmogorov-Smirnov's Test of Normality & .153 \\
Tests of Between-Subjects Effects (Homogeneity of the regression slope) & .268 \\
Tests of Between-Subjects Effects (Homogeneity of the regression slope) & .000 \\
\hline
\end{tabular}

As the assumptions were met, we run the ANCOVA test for the students' grammatical accuracy. As indicated in Table 6, the results of ANCOVA indicated a significant difference between the performance of the experimental group in the posttest $(\mathrm{F}=$ 13.558, Sig.= .001). Therefore, it can be concluded that totally, students in the experimental group had less grammatical errors in the posttest which confirms the positive influence of Noticing on reducing their grammatical errors. 
Table 6

Tests of Between-Subjects Effects

\begin{tabular}{lllllll}
\hline \multicolumn{7}{c}{ Dependent Variable: Grammar Posttest } \\
\hline Source & $\begin{array}{l}\text { Type III Sum } \\
\text { of Squares }\end{array}$ & df & Mean Square F & Sig. & Partial Eta \\
Corrected Model & $.008^{\mathrm{a}}$ & 2 & .004 & 26.357 & .000 & .645 \\
Intercept & .000 & 1 & .000 & 2.248 & .145 & .072 \\
Grammar Pretest & .007 & 1 & .007 & 48.544 & .000 & .626 \\
Group & .002 & 1 & .002 & 13.558 & .001 & .319 \\
Error & .004 & 29 & .000 & & & \\
Total & .089 & 32 & & & & \\
Corrected Total & .012 & 31 & & & & \\
\hline
\end{tabular}

\section{Phonological Errors}

\section{Descriptive statistics of phonological errors}

As indicated in Table 7, students had 325 phonological errors in their posttest and 558 phonological errors in their pretest. The Table also shows the students' phonological errors divided by the number of words in their posttest $(\mathrm{Sum}=7.69)$ and pretest $(\mathrm{Sum}=$ 11.81).

Table 7

Descriptive statistics of students' phonological errors in the pretest and posttest

\begin{tabular}{|c|c|c|c|c|c|c|}
\hline & $\mathrm{N}$ & Minimum & Maximum & Sum & Mean & Std. Deviation \\
\hline $\begin{array}{l}\text { Phonological Errors in } \\
\text { Pretest }\end{array}$ & 32 & 6.00 & 39.00 & 558.00 & 17.4375 & 7.47442 \\
\hline $\begin{array}{l}\text { Phonological Errors in } \\
\text { Posttest }\end{array}$ & 32 & .00 & 28.00 & 325.00 & 10.1563 & 6.79236 \\
\hline $\begin{array}{l}\text { Phonological Errors in } \\
\text { Pretest Divided by Words }\end{array}$ & 32 & .06 & .76 & 11.81 & .3692 & .15244 \\
\hline $\begin{array}{l}\text { Phonological Errors in } \\
\text { Posttest Divided by } \\
\text { Words }\end{array}$ & 32 & .00 & .56 & 7.69 & .2402 & .14431 \\
\hline
\end{tabular}

\section{The Influence of Noticing on Students' Phonological Accuracy}

As it is indicated in Table 8, Levene's test of Equality of Variances shows that the variances of errors are equal since the Sig. is more than .05. Therefore, this assumption is met. As indicated in the Table, Kolmogorov-Smirnov's test shows that the residual of the model is normal as the Sig. is more than .05.

Another assumption of ANCOVA which is the homogeneity of the regression slope, was met as the Sig. is .136, as indicated in Table 8. This assumption is met because the interaction of Group * Phonology Pretest is not significant (sig. > .05). Besides, the last 
assumption of ANCOVA which is the linearity of regression line was also met because the Sig. is .000, as indicated in the Table. This assumption is also met as the interaction of Phonology Pretest is significant (sig. <.05).

Table 8

Assumptions of ANCOVA for Students' Phonological Accuracy

\begin{tabular}{ll}
\hline Assumptions & Sig. \\
\hline Levene's Test of Equality of Error Variances & .166 \\
Kolmogorov-Smirnov's Test of Normality & .200 \\
Tests of Between-Subjects Effects (Homogeneity of the regression slope) & .136 \\
Tests of Between-Subjects Effects (Homogeneity of the regression slope) & .000 \\
\hline
\end{tabular}

After checking the assumptions, we ran the ANCOVA test for the students' phonological accuracy. As indicated in Table 9, the results of ANCOVA indicated a significant difference between the performance of the experimental group in the posttest $(\mathrm{F}=7.902$, Sig.= .009). Therefore, it can be concluded that totally, students in the experimental group had less phonological errors in the posttest which confirms the positive influence of Noticing on reducing their errors.

Table 9

Tests of Between-Subjects Effects

\begin{tabular}{lllllll}
\hline \multicolumn{7}{c}{ Dependent Variable: Phonology Posttest } \\
\hline Source & $\begin{array}{l}\text { Type III Sum } \\
\text { of Squares }\end{array}$ & df & Mean Square & F & Sig. & Partial Eta \\
Corrected Model & $.295^{\text {a }}$ & 2 & .148 & 12.237 & .000 & .458 \\
Intercept & .007 & 1 & .007 & .591 & .448 & .020 \\
Phonology & .212 & 1 & .212 & 17.560 & .000 & .377 \\
Pretest & .095 & 1 & .095 & 7.902 & .009 & .214 \\
Group & .350 & 29 & .012 & & & \\
Error & 2.491 & 32 & & & & \\
Total & .646 & 31 & & & & \\
Corrected Total & .600 & & &
\end{tabular}

\section{Lexico-semantic Errors}

\section{Descriptive statistics of lexico-semantic errors}

As shown in Table 10, the number of lexico-semantic errors that the students had in their pretest and posttest were 98 and 36 respectively. In addition, the following Table indicates the Sum of the number of learners' lexico-semantic errors divided by the number of the words they said for their pretest and posttest which are .27 and .08 respectively. 
Table 10

Descriptive Statistics of Students' Lexico-Semantic Errors in the Pretest and Posttest

\begin{tabular}{|c|c|c|c|c|c|c|}
\hline & $\mathrm{N}$ & Minimum & Maximum & Sum & Mean & Std. Deviation \\
\hline $\begin{array}{l}\text { Lexico-Semantic Errors in } \\
\text { Pretest }\end{array}$ & 32 & 1.00 & 4.00 & 98.00 & 3.0625 & 1.04534 \\
\hline $\begin{array}{l}\text { Lexico-Semantic Errors in } \\
\text { Posttest }\end{array}$ & 32 & .00 & 2.00 & 36.00 & 1.1250 & .60907 \\
\hline $\begin{array}{l}\text { Lexico-Semantic Errors in } \\
\text { Pretest Divided by Words }\end{array}$ & 32 & .00 & .02 & .27 & .0085 & .00440 \\
\hline $\begin{array}{l}\text { Lexico-Semantic Errors in } \\
\text { Posttest Divided by Words }\end{array}$ & 32 & .00 & .01 & .08 & .0026 & .00167 \\
\hline
\end{tabular}

\section{The Influence of Noticing on Students' Lexico-Semantic Accuracy}

As shown in Table 11, Levene's test of Equality of Variances shows that the variances of errors are equal since the Sig. is more than .05. As indicated in the Table, Kolmogoro- Smirnov's test shows that the residual of the model is normal as the Sig. is more than .05 .

The homogeneity of the regression slope, as the third assumption of ANCOVA was met as the Sig. is .655, as indicated in Table 11. This assumption is met because the interaction of Group * Lexical Pretest is not significant (Sig. > .05). Moreover, the last assumption of regression which is the linearity of regression line was also met as the sig. is .003, as shown in Table 11. This assumption is also met as the interaction of Lexical Pretest is significant (sig. <.05).

Table 11

Assumptions of ANCOVA for Students' Lexico-Semantic Accuracy

\begin{tabular}{ll}
\hline Assumptions & Sig. \\
\hline Levene's Test of Equality of Error Variances & .713 \\
Kolmogorov-Smirnov's Test of Normality & .200 \\
Tests of Between-Subjects Effects (Homogeneity of the regression slope) & .665 \\
Tests of Between-Subjects Effects (Homogeneity of the regression slope) & .003 \\
\hline
\end{tabular}

Now that the 4 assumptions were met, ANCOVA test for the students' lexico-semantic accuracy can be run. As shown in Table 12, the results of ANCOVA indicated a significant difference between the performance of the experimental group in the posttest $(\mathrm{F}=6.961$, sig.= .013). Thus, it can be concluded that totally, students in the experimental group had less lexico-semantic errors in the posttest which confirms the positive influence of Noticing on reducing their errors. 
Table 12

Tests of Between-Subjects Effects

\begin{tabular}{lllllll}
\hline \multicolumn{7}{c}{ Dependent Variable: Lexical Posttest } \\
\hline Source & $\begin{array}{l}\text { Type III Sum } \\
\text { of Squares }\end{array}$ & df & Mean Square & F & Sig. & Squared \\
Corrected Model & $3.169 \mathrm{E}-5^{\mathrm{a}}$ & 2 & $1.584 \mathrm{E}-5$ & 8.327 & .001 & .365 \\
Intercept & $6.810 \mathrm{E}-6$ & 1 & $6.810 \mathrm{E}-6$ & 3.580 & .069 & .110 \\
Lexical Pretest & $2.197 \mathrm{E}-5$ & 1 & $2.197 \mathrm{E}-5$ & 11.548 & .002 & .285 \\
Group & $1.324 \mathrm{E}-5$ & 1 & $1.324 \mathrm{E}-5$ & 6.961 & .013 & .194 \\
Error & $5.518 \mathrm{E}-5$ & 29 & $1.903 \mathrm{E}-6$ & & & \\
Total & .000 & 32 & & & & \\
Corrected Total & $8.686 \mathrm{E}-5$ & 31 & & & & \\
\hline
\end{tabular}

To summarize the results, after checking the assumptions and running ANCOVA, the results indicated a significant difference between the performance of the experimental group in the posttest in Total accuracy ( $\mathrm{F}=17.105$, Sig.=.000), Grammatical accuracy $(\mathrm{F}=13.558$, Sig.=.001), Phonological accuracy ( $\mathrm{F}=7.902$, Sig.=.009), and Lexicosemantic accuracy (F=6.961, Sig.=.013), as shown in Table 13.

Table 13

Summary of the Results for Learners

\begin{tabular}{lllllll}
\hline & $\begin{array}{l}\text { Type III Sum of } \\
\text { Squares }\end{array}$ & df & $\begin{array}{l}\text { Mean } \\
\text { Square }\end{array}$ & F & Sig. & $\begin{array}{l}\text { Partial Eta } \\
\text { Squares }\end{array}$ \\
\hline Total Accuracy & .008 & 1 & .008 & 17.105 & .000 & .371 \\
Grammatical Accuracy & .002 & 1 & .002 & 13.558 & .001 & .319 \\
Phonological Accuracy & .095 & 1 & .095 & 7.902 & .009 & .214 \\
Lexico-Semantic & 1.324 & 1 & 1.324 & 6.961 & .013 & .194 \\
Accuracy & 1.95 & & & \\
\hline
\end{tabular}

\section{DISCUSSION AND CONCLUSION}

The purpose of this study was to investigate the effect of noticing on EFL students' speaking accuracy. The findings indicated that noticing had a positive effect on the EFL learners' grammatical, phonological and lexico-semantic accuracy. These results are in line with many previous studies substantiating the beneficial effect of noticing on language learning (Abdalla, 2014; Baleghizadeh \& Derakhshesh, 2012; Jafarpour Mamaghani \& Birjandi, 2017; Khatib \& Alizadeh, 2012; Mackey, 2006; Mennim, 2007; Mirzaei, et al., 2012).

In line with Baleghizadeh and Derakhshesh's (2012) findings, the present study showed that by transcribing their voices, students could notice the errors they had in their speaking more, which ultimately resulted in more accurate speaking. Similarly, the findings of this study supported the results of Mennim's (2007) longitudinal study showing that noticing had a positive effect on students' language accuracy.

The results of this study showed that students in the experimental group that had more opportunities for noticing had less grammatical errors in the posttest. This is in line with 
the findings of the Ögeyik's (2017) review of 41 published papers showing a positive impact of noticing on language learning. Furthermore, the findings supports Jafarpour Mamaghani and Birjandi's (2017) study that showed the facilitative effects of oral pushed output on the learning and retention of English perfect tenses. Besides, the study by Mirzaei, et al., (2012) indicated that noticing can improve students' use of English intonation patterns which is in line with the findings of this study.

However, there is a difference between the methodology chosen in this study and the previous ones examining the effect of noticing of EFL student accuracy (e.g. Baleghizadeh \& Derakhshesh, 2012; Jafarpour Mamaghani \& Birjandi, 2017; Mennim, 2007; Mirzaei et al., 2012) in that most of the previous studies have singled out one or two grammatical features or some aspects of speaking accuracy and examined the effect of noticing on them. However, the present study aimed to conduct a comprehensive research on the effect of noticing on the learners' grammatical, phonological and lexicosemantic accuracy based on a model of error analysis.

The findings of this study are also in line with Schmidt's (1990) Noticing Hypothesis claiming that "subliminal language learning is impossible, and that intake is what learners consciously notice" (p. 149). In the present study, the students in the experimental groups had different opportunities for noticing. Firstly, they were asked to transcribe their voices. By doing so, they could have a conscious attention of the language they produced and they could recognize the majority of speaking errors they had. Secondly, they were asked to classify their errors in a Table which was prepared based on Keshavarz's (1999) Model of Error Analysis. This also gave the learners the chance to focus on the type of the errors they had. Thirdly, the students' voices and their identified errors were meticulously checked by the course instructors and they were informed of the errors that they could not identify. Going through these steps gave the learners the opportunities to notice the language and be aware of the errors they had.

However, the findings of this study did not support Krashen and Terrell's Natural Approach as students with more noticing had less errors in the speaking posttest. This may stem from the fact that first language acquisition and foreign language learning have different processes. In fact, some parts of English language grammar are too difficult for students to learn without conscious attention and noticing. This is also in line with the findings of some naturalistic and immersion programs showing that if instruction just focus on meaning, students cannot accurately learn some linguistic features (Williams, 1999).

Based on the obtained results, it was concluded that noticing had a significantly positive effect on EFL learners' speaking accuracy. The findings can add to the related literature of the importance of noticing in learning language skills. The results can also inform EFL learners about the significant role of noticing in reducing their speaking errors. Considering the findings, it is suggested that EFL teachers provide more tasks and opportunities for learners in order to help them notice the input. One useful activity can be to ask the learners to talk in the class and record their voice and then transcribe it to be informed of the errors and mistakes that they have. While doing this task, the teachers 
should not only help the learners in finding their speaking errors but also encourage them not to repeat those errors while speaking in the future.

Furthermore, given the facilitative role of noticing in the process of language learning, it is recommended that the materials designers include some tasks and activities in the teaching materials to help learners notice the input. Additionally, as some language teachers may not be aware of the important role of noticing in the process of language learning, pre-service and in-service teacher education programs should inform EFL teachers of the significant role of noticing in language education and the effective methods that can be used to boost learners' noticing and focus on form.

The present study tried to shed some lights on the effects of noticing on EFL students' speaking accuracy. However, the study had some limitations that should be considered while interpreting the findings. Firstly, the participants of the study were not selected randomly as they had already registered in the university as freshman students, although a language proficiency test was conducted before running the study to be sure about their homogeneity. Secondly, even though the experiment lasted for 32 sessions (each lasted for one hour and a half), the number of participant was 32 that can prevent us from generalizing the findings.

Considering these limitations and the paucity of studies on how noticing can help EFL learners improve their language proficiency, it is suggested that other researchers continue this line of research to shed more lights on the effect of noticing on language learning. For example, other researchers can examine if noticing has different levels of effectiveness on students having different ages, gender, and/or proficiency levels. In addition, the effect of noticing on learning other language skills is another area that can be addressed in the future studies.

\section{REFERENCES}

Abdalla, A. H. (2014). Investigating the Effect of Consciousness-raising Techniques on Learning the English Tense System by EFL Students. Journal of Language Teaching and Research, 5(4), 810-818.

Baleghizadeh, S. \& Derakhshesh, A. (2012). The Effect of Task Repetition and Noticing on EFL Learners' Oral Output. International Journal of Instruction, 5 (1), 141-152.

Bergsleithner, J. M. (2007). Working memory capacity, noticing and L2 speech production. Unpublished doctoral dissertation. Florianópolis: Universidade Federal de Santa Catarina, Florianópolis.

Gan, Zh. (2012). Understanding L2 Speaking Problems: Implications for ESL Curriculum Development in a Teacher Training Institution in Hong Kong. Australian Journal of Teacher Education, 37 (1), 42-59.

Izumi, S. (2013). Noticing and L2 development: theoretical, empirical and pedagogical issues. In J. M. Bergsleithner, S. N. Frota, \& J. K. Yoshioka (Eds.), Noticing and second language acquisition: Studies in honor of Richard Schmidt (pp. 25-38). Honolulu: University of Hawai'i, National Foreign Language Resource Center. 
Jafarpour Mamaghani, H., \& Birjandi, P. (2017). Oral Pushed Output: The Route to Long-term Grammatical Accuracy. Journal of Teaching Language Skills, 36(1), 57-84.

Keshavarz, M. H. (1999). Contrastive analysis and error analysis. Tehran: Rahnama Publications.

Khatib, M. \& Alizadeh, M. (2012). Output Tasks, Noticing, and Learning: Teaching English Past Tense to Iranian EFL Students. English Language Teaching, 5 (4), 173187.

Krashen, S. (1981). Second Language Acquisition and Second Language Learning. Englewood Cliffs, N. J.: Prentice Hall.

Krashen, S. (1982). Principles and Practice in Second Language Acquisition. Englewood Cliffs, N. J.: Prentice Hall.

Krashen, S. (1985). The Input Hypothesis. London: Longman.

Lee, G. (2009). Six Korean Students' Oral Participation in Class Siscussions in US Graduate Seminars. English for Specific Purposes, 28(3), 142-156.

Mackey, A. (2006). Feedback, Noticing and Instructed Second Language Learning. Applied Linguistics, 27(3), 405-430.

Mennim, P. (2007). Long-term Effects of Noticing on Oral Output. Language Teaching Research, 11(3), 265-280. http://dx.doi.org/10.1177/1362168807077551.

Mirzaei, A., Abdollahian, Z., \& Ranjbar, M. (2012). The Role of Noticing in L2 Learners' Production of Intonation Patterns. The Journal of Teaching Language Skills (JTLS), 4(1), 141-170.

Morita, N. (2000). Discourse Socialization Through Oral Classroom Activities in a TESL Graduate Classroom. TESOL Quarterly, 34 (2), 279-310.

Muhamad, A. J., Shah, M. A. I., Ibrahim, E. E. H., Sarudin, I., Malik, F. A. \& Ghani, R. A. (2013). Oral presentation errors of Malaysian students in an English for Academic Purposes (EAP) course. World Applied Sciences Journal, 21 (Special Issue of Studies in Language Teaching and Learning), 19-27.

Nazarloo, S., \& Navidinia, H. (2016). Speaking Errors of Persian and Azeri Turkish Learners in EFL Classrooms: A Comparative Investigation. International Journal of English Language and Translation Studies, 4 (4), 99-197.

Ögeyik, M. C. (2017). The Comparative Effectiveness of Noticing in Language Learning. International Review of Applied Linguistics in Language Teaching, 1-23, DOI 10.1515/iral-2016-0049.

Richards, J. C. (2008). Teaching Listening and Speaking. Cambridge, England: Cambridge University Press.

Schmidt, R. (1990). The Role of Consciousness in Second Language Learning. Applied Linguistics, 11 (2), 129-158. 
Schmidt, R. (1995). Consciousness and foreign language learning: A tutorial on the role of attention and awareness and learning. In R. Schmidt (Ed.), Attention and awareness in foreign language learning (pp. 1-63). Honolulu, HI: University of Hawai'I, National Foreign Language Resource Center.

Schmidt, R. (2010). Attention, awareness, and individual differences in language learning. In W. M. Chan, S. Chi, K. N. Cin, J. Istanto, M. Nagami, J. W. Sew, T. Suthiwan, \& I. Walker, Proceedings of CLaSIC 2010, Singapore, December 2-4 (pp. 721-737). Singapore: National University of Singapore, Centre for Language Studies.

Schmidt, R. W., \& Frota, S. (1986). Developing basic conversational ability in a second language: A case study of an adult learner of Portuguese. In R. R. Day (Ed.), Talking to learn: Conversation in second language acquisition (pp. 237-326). Rowley, MA: Newbury House.

Shekari, M. \& Tahririan M. H. (2006). Negotiating of Meaning and Noticing in Textbased Online cCat. The Modern Language Journal, 90 (4), 557-573.

Skehan, P. (2013). Nurturing noticing. In J. M. Bersleithenr, S. N. Frota, \& J. K. Yoshioka (Eds.), Noticing and second language acquisition: Studies in honor of Richard Schmidt (pp. 169-180). Honolulu: University of Hawai'i, National Foreign Language Resource Center.

Swain, M. (1985). Communicative competence: Some roles of comprehensible input and comprehensible output in its development. In S. Gass \& C. Madden (Eds.), Input in Second Language Acquisition (pp.235-253). Rowley, MA: Newbury House.

Swain, M. (1995). Three functions of output in second language learning. In G. Cook \& B. Seidlhofer (Eds.), Principle and Practice in Applied Linguistics: Studies in Honour of H. G. Widdowson (pp. 125-44). Oxford: Oxford University Press.

Swain, M. (2005). The Output Hypothesis: Theory and Research. In E. Hinkel (Ed.), Handbook of Research in Second Language Teaching and Learning (pp.471-483). Mahwah, NJ: Lawrence Erlbaum.

Swain, M., Lapkin, S. (1995). Problems in Output and the Cognitive Processes They Generate: A Step Towards Second Language Learning. Applied Linguistics, 16(3): 371391.

Williams, J. (1999). Learner-generated Attention to Form. Language Learning, 49 (4), 583-625. 